\title{
Luteal inadequacy during the early luteal phase of subfertile cows*
}

\author{
K. Shelton, M. F. Gayerie De Abreu, M. G. Hunter, T. J. Parkinson† and \\ G. E. Lamming
}

AFRC Research Group on Hormones and Farm Animal Reproduction, University of Nottingham, Sutton Bonington, Leics LE12 5RD, UK

\begin{abstract}
Summary. A study was made of early luteal function (up to Day 6) in cyclic and pregnant heifers and also in older, subfertile cows. There were no differences in vivo or in vitro between cyclic and pregnant heifers, indicating no luteotrophic effect of the embryo at this stage, but the increase in postovulatory peripheral progesterone concentrations was delayed $(P<0.01)$ and occurred more slowly $(P<0.001)$ in the subfertile cows than in the heifers. The corpora lutea of the subfertile cows were heavier $(P<0.001)$ than those of the heifers on Day 6. Basal progesterone production by dispersed luteal cells was similar between heifers and subfertile cows, but there was a difference $(P<0.001)$ in the pattern of response to exogenous LH and PGE-2. Cells from subfertile cows were less sensitive to the stimulatory effects of PGE-2 and although $\mathrm{LH}$ increased $(P<0.001)$ progesterone production by all cells, this stimulation by a low dose of LH was inhibited by PGE-2 in luteal cells from subfertile cows. This effect did not occur in the luteal cells from heifers. These results indicate the possibility that luteal inadequacy, due to a diminished response to circulating luteotrophic hormones, may contribute to embryo mortality in subfertile cows.
\end{abstract}

Keywords: luteal inadequacy; subfertility; cows

\section{Introduction}

Reproductive failure, largely as a result of embryo mortality, is a major factor affecting production in beef and dairy herds. Even in well managed herds, not more than $60 \%$ of cattle calve after a single insemination (see Sreenan \& Diskin, 1986). The increased incidence of embryo loss in repeatbreeder cattle (defined as cows which had been inseminated at least 4 times without conception) (Ayalon, 1978, 1984) and in older cows after their fifth lactation (Boyd \& Reed, 1961; Ball, 1978) results in a further reduction in calving rate.

Although it is established that the extent of embryonic loss is substantial, its causes are poorly understood. In repeat-breeders, the time when the embryo enters the uterus and undergoes blastocoele formation (Days 6-8) has been suggested to be a critical period during which embryo death occurs (Ayalon, 1978; Maurer \& Chenault, 1983). Adequate luteal function before this may be of major importance since normal embryonic development depends upon sequential changes in uterine secretions under the influence of progesterone (Wilmut et al., 1986). The efficiency of the corpus luteum in early pregnancy may be determined by maternal factors; however, the embryo itself may also provide direct or indirect luteotrophic support. Peripheral progesterone concentrations have been reported to be elevated during the first week of pregnancy by some workers (Randel et al., 1971; Erb et al., 1976; Maurer \& Echternkamp, 1982; Lee et al., 1985) but not by

${ }^{*}$ Reprint requests to Dr M. G. Hunter.

†Present address: Department of Veterinary Surgery, University of Bristol, Langford, Bristol BSI8 7DU, UK. 
others until Days 9-13 (Henricks et al., 1970, 1971; Holness et al., 1977; Bulman \& Lamming, 1978; Lukaszewska \& Hansel, 1980; Lamming et al., 1989). While an early divergence between pregnant and inseminated animals that fail to become pregnant may reflect the luteotrophic effect of the embryo, it could indicate a luteal deficiency in inseminated animals which fail to become pregnant and would suggest embryonic death as the result rather than the cause of this inadequacy.

The objectives of this study were to define the normal pattern of progesterone secretion during the early luteal phase of cattle with potentially normal fertility (virgin heifers), and to determine whether the embryo has a luteotrophic effect in vivo; to investigate the possibility that embryo mortality in subfertile cows is due to inadequate corpus luteum function during the early luteal phase, by comparing plasma progesterone patterns with those of fertile animals; and, lastly, to correlate these findings with the performance of the corpus luteum of fertile and subfertile cattle in the terms of the ability of the luteal cells in vitro to synthesize progesterone under control conditions and in response to the luteotrophic hormones, $\mathrm{LH}$ and prostaglandin (PG) E-2.

\section{Materials and Methods}

Animals and blood sampling. All experimental work was carried out during the summer (May-September) at latitude $51^{\circ} \mathrm{N}$. A total of 40 mature Hereford $\times$ Friesian heifers at approximately 18 months of age were obtained for the first part of the experiment $(350-440 \mathrm{~kg}$ in weight). Alternate batches of heifers were artificially inseminated with frozen semen from a single bull tested for high fertility and known to be free of karyotype abnormalities of blood cells (pregnant group) or sham-inseminated using killed semen from the same source (cyclic group). The semen was killed by withdrawing it from liquid nitrogen $\left(-196^{\circ} \mathrm{C}\right)$, thawing it and then replacing it directly into the liquid nitrogen. The procedure was then repeated to ensure that the spermatozoa were inactivated by freezing damage.

A total of 15 Friesian cows ranging in age from 7 to 13 years which were to be culled because of infertility were used in the second part of the experiment. The reproductive history of all the cows was available: 7 had failed to conceive after 2-5 services and 2 had not been observed in oestrus for about 1 year. All had previously normal calving records. Each animal had at least 1 oestrous cycle (determined either by observation of behavioural oestrus or by measurement of peripheral plasma progesterone concentrations, or both) before entering the experimental group. Most of these females were cytogenetically examined, by culturing and karyotyping peripheral blood lymphocytes, and no chromosome aberrations were detected in these samples. The cows were artificially inseminated using the same batch of frozen semen as that used for the heifers. Of the 15 cows initially in the the study, 4 were eliminated since it was not possible to maintain the cannulae continuously in them, and so only 11 cows had frequent blood samples taken from them over the whole experiment and were included in the final analysis.

During the experimental period, each animal had one jugular vein cannulated on the day before blood sampling. Oestrous cycles were synchronized using $2 \mathrm{i} . \mathrm{m}$. injections of $500 \mu \mathrm{g}$ cloprostenol (Estrumate: Coopers Animal Health Ltd, Crewe, Cheshire, UK) (PG) administered 11 days apart. Insemination took place at 72 and $96 \mathrm{~h}$ after the second PG injection (PG2). Jugular venous blood samples were collected every 2 or $4 \mathrm{~h}$ from time of the second PG injection. The cattle were slaughtered on Day 6 of the cycle or pregnancy, Day 1 being the day of the first insemination.

Procedure at slaughter of animals. The reproductive tract was placed on ice and transported to the laboratory within 10 min of slaughter and the corpus luteum enucleated. The remainder of the tract was flushed for embryo/ ovum recovery. Two clamps were applied to the uterus, 1 caudal to the utero-cervical junction. The oviduct was then dissected free and severed above the first clamp: $10 \mathrm{ml}$ chilled Dulbecco's phosphate-buffered saline (PBS) (Whittingham, 1971) supplemented with $1 \%$ sheep serum were flushed through the oviduct from the ampulla to the utero-tubal junction and collected into a glass egg collection cup. A further $30 \mathrm{ml}$ medium were flushed from the cervical end to the utero-tubal junction. The utero-tubal clamp was removed and the medium carefuly transferred into 2 or 3 egg collection cups. The contents of the cups were then examined under the stereomicroscope. The quality of the embryo based on chromosomal analyses and stage of development of the embryo were recorded. No increase in chromosomal abnormality was noted in cows compared with heifers (Gayerie De Abreu et al., 1984).

Luteal tissue dissociation. The corpus luteum was dissected out and its weight and morphological appearance were recorded. The tissue was then enzymically dissociated based on the procedure of Henderson \& Moon (1979), using $0.2 \%$ collagenase (Type II, Sigma Chemical Co. Ltd, Poole, Dorset, UK). The cells were counted in duplicate and their viability estimated using the trypan blue exclusion test (Tennant, 1964). The luteal cells were incubated at a final concentration of $5 \times 10^{4}$ viable cells $/ \mathrm{ml}$ in tubes containing control Eagle's Modified Medium with Earle's Salts plus 20 mM-Hepes buffer (Eagle's Medium) (Flow Labs, Irvine, UK) or LH (Bovine LH-NIH B9) and/or PGE-2 (Sigma) as follows; 0.1 or $100 \mathrm{ng} \mathrm{LH} / \mathrm{ml}, 0.01-1000 \mathrm{ng} \mathrm{PGE}-2 / \mathrm{ml}, 0.01-1000 \mathrm{ng} \mathrm{PGE-2} / \mathrm{ml}$ plus $0.1 \mathrm{ng} \mathrm{LH} / \mathrm{ml}$, or 0.01-1000 ng PGE-2/ml plus $100 \mathrm{ng} \mathrm{LH} / \mathrm{ml}$, in Eagle's Medium. Incubations were performed in replicates of 5. Five control tubes were immediately capped and frozen at $-20^{\circ} \mathrm{C}$ for later estimation of the amount of progesterone present at the start of the incubation (Time 0 ). The remaining tubes were capped and incubated for $3 \mathrm{~h}$ at $37^{\circ} \mathrm{C}$ in a shaking water bath at 60 cycles/min before storage at $-20^{\circ} \mathrm{C}$ and subsequent assay for progesterone. 
Hormone radioimmunoassays. Plasma LH concentrations were measured by a double-antibody radioimmunoassay procedure (Convey et al., 1976), the specificity data for which were described by Webb et al. (1977). The limit of sensitivity of the assay was $0.23 \mathrm{ng}$ NIH-LH-B9 equiv./ml plasma and the inter- and intra-assay coefficients of variation were 12.3 and $10 \cdot 3 \%$ respectively.

Plasma progesterone concentrations were measured using the method of Haresign et al. (1975) with modifications as described by Hunter et al. (1986). The limit of sensitivity was $0.17 \mathrm{ng} / \mathrm{ml}$ plasma, the mean extraction efficiency was $74 \pm 4.5 \%$ and the inter- and intra-assay coefficients of variation were $15 \cdot 5$ and $14 \cdot 1 \%$ respectively.

The concentration of progesterone in incubation medium was measured using the technque described for plasma, except that the samples were assayed directly without prior extraction. The results obtained by direct assay were comparable to those obtained using extraction for incubation medium plus $(r=0.997)$ or minus $(r=0.998)$ cells. Serial dilutions of incubation medium plus cells showed parallelism with the standard curve. The inter- and intra-assay coefficients of variation were $<10 \%$.

Luteal function in vivo. The pattern of progesterone secretion was measured in all groups of heifers and cows. The parameters determined were: (i) the time taken for plasma progesterone concentrations to decline, (ii) the time taken from the preovulatory LH peak for progesterone secreted by the new corpus luteum to appear in the peripheral plasma, and (iii) the rate at which the progesterone concentration then rose in the plasma. The timing of the occurrence of the LH peak in relation to the second PG injection and the duration of the peak were also calculated. Figure I shows representative plasma and LH profiles from one heifer, and indicates the periods of time under consideration.

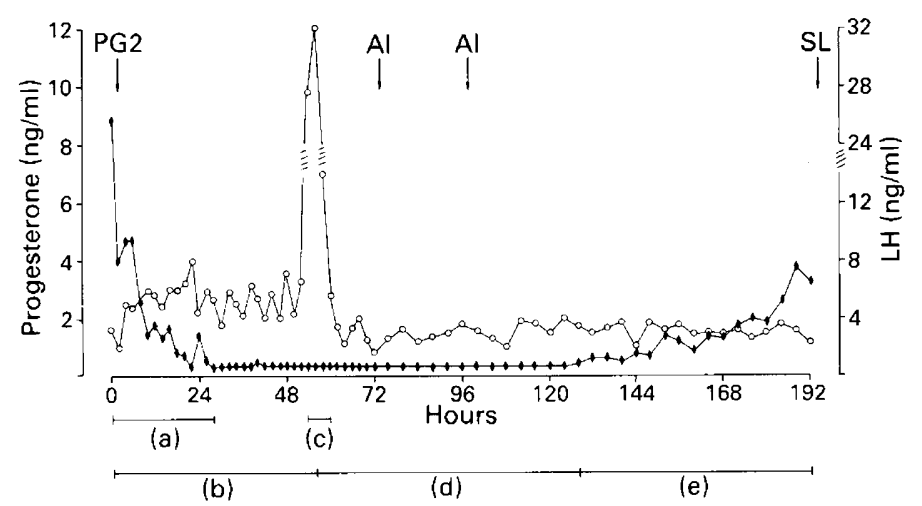

Fig. 1. Representative profiles of plasma progesterone $(\bullet)$ and $\mathrm{LH}(\mathrm{O})$ from a heifer during the first 6 days of pregnancy. The time periods examined were: (a) the plasma progesterone decline, (b) the time of occurrence of the preovulatory LH peak, (c) the duration of the preovulatory $\mathrm{LH}$ peak, (d) the interval from the LH peak to the post-ovulatory progesterone rise and (e) the progesterone rise. $\mathrm{PG} 2$ = second injection of cloprostenol; $\mathrm{AI}=$ artificial insemination; $\mathrm{SL}=$ slaughter.

The time taken for plasma progesterone concentrations to decline after the second PG injection, the timing of the postovulatory rise in plasma progesterone, together with the time of occurrence and the duration of the preovulatory LH peak in the different groups are shown in Table 1. The progesterone decline was calculated by measuring the interval (h) from second PG injection to the first plasma sample with an undetectable progesterone concentration (as defined by the amount distinguishable from zero with a $95 \%$ confidence limit). The interval from the LH peak to the beginning of the progesterone rise was taken as the time (h) from the maximum value of $\mathrm{LH}$ measured during the preovulatory peak to the first progesterone value obtained of $1 \mathrm{ng} / \mathrm{ml}$ plasma or greater followed by 2 consecutive values at that concentration or above. The time of occurrence of the LH peak was calculated by measuring the interval from the second PG injection to the maximum value of the LH peak. The duration of the peak was defined as the period from the beginning of the surge (i.e. the first LH value above the mean of pre-surge concentrations + $($ s.e.m. $\times 2$ ) followed by 2 values above that concentration) to the end of the surge (i.e. the first value below the mean pre-surge concentration $+($ s.e.m. $\times 2)$ followed by 2 values below that concentration).

The ages of corpora lutea collected from each group of cattle after slaughter were calculated by measurement of the time interval (h) between the maximum value in the preovulatory LH peak to the time of slaughter (h after $\mathrm{LH}$ peak).

Statistical analyses. Differences in the post-ovulatory plasma progesterone rise in peripheral blood between the groups of animals were investigated by comparing the regression lines of plasma progesterone concentration using analysis of variance. Other characteristics were compared by analysis of variance. The variation in progesterone 
Table 1. The time of the progesterone decline, time of occurrence and duration of the preovulatory $\mathrm{LH}$ peak and the time of the rise in progesterone concentration in plasma of heifers and subfertile cows during the first 6 days of the oestrous cycle or pregnancy

\begin{tabular}{|c|c|c|c|c|}
\hline & \multirow{2}{*}{$\begin{array}{l}\text { Progesterone } \\
\text { decline } \\
\text { (h) }\end{array}$} & \multicolumn{2}{|c|}{ Preovulatory LH peak } & \multirow{2}{*}{$\begin{array}{l}\text { Post-ovulatory } \\
\text { progesterone } \\
\text { rise } \\
\text { (h) }\end{array}$} \\
\hline & & $\begin{array}{l}\text { Occurrence } \\
\text { (h) }\end{array}$ & $\begin{array}{l}\text { Duration } \\
\text { (h) }\end{array}$ & \\
\hline Cyclic heifers & ${ }_{(13)}^{29 \cdot 4 \pm} 8 \cdot 8$ & $\begin{array}{c}59 \cdot 5 \pm 24 \cdot 2 \\
(13)\end{array}$ & ${ }_{(13)}^{11 \cdot 7} \pm 2 \cdot 6$ & $\begin{array}{c}85 \cdot 2 \pm 3 \cdot 4 \\
(12)\end{array}$ \\
\hline Pregnant heifers & $\begin{array}{c}42 \cdot 5 \pm 18 \cdot 4 \\
(20)\end{array}$ & ${ }_{(20)}^{75 \cdot 6 \pm 25 \cdot 5}$ & $\begin{array}{c}12 \cdot 3 \pm 3 \cdot 1 \\
(20)\end{array}$ & $\begin{array}{c}90 \cdot 1 \pm 3 \cdot 0 \\
(15)\end{array}$ \\
\hline Subfertile cows & $\frac{28 \cdot 1 \pm 18 \cdot 4}{(11)}$ & $\begin{array}{c}67 \cdot 3 \pm 14 \cdot 7 \\
(11)\end{array}$ & $\begin{array}{c}10 \cdot 4 \pm 2 \cdot 8 \\
\quad(11)\end{array}$ & $107 \cdot 1 \underset{(9)}{ \pm} 4 \cdot 0^{*}$ \\
\hline
\end{tabular}

Each value represents the mean \pm s.d. and numbers in parentheses show the number of animals. Definitions of the endocrine measurements are in the text.

${ }^{*}$ Significantly different from the heifer groups $(P<0.01)$.

content between luteal cell incubations was partitioned using a three factor analysis of variation (groups, dose of LH and dose of PGE-2). The initial concentration of progesterone present at the start of the incubation (Time 0 ) was used as a co-variate to adjust for any variation at that time.

\section{Results}

\section{Luteal function in vivo}

Any animals which were found to have abnormal genitalia or which did not respond to the PG injection were excluded. Plasma hormone data are presented from 33 of the 40 heifers and from 11 subfertile cows. Data from 20 heifers were included in the pregnant and 13 in the cyclic group. Of the pregnant group, 17 heifers had morphologically normal embryos, ranging in development from 4 to 32 cells. No embryo was recovered from 3 heifers but since progesterone production in vivo and in vitro was not different from heifers in which an embryo was recovered, all these animals were considered as one group. Embryos were recovered from 8 of the subfertile cows. From 2 further cows an empty zona pellucida was recovered and no embryo was recovered from 1 cow. For analysis, these 11 animals were considered together as the subfertile cow group. The developmental stage of the embryos recovered from cows ranged from 8 to 30 cells.

The interval between the $\mathrm{LH}$ peak and the beginning of the progesterone rise was significantly $(P<0.01)$ longer in cows than in pregnant or cyclic heifers $(107.1 \pm 4.0 \mathrm{~h}(\mathrm{~N}=9), 90.1 \pm 3.0 \mathrm{~h}$ $(\mathrm{N}=15)$, and $85 \cdot 2 \pm 3 \cdot 4 \mathrm{~h}(\mathrm{~N}=12)$, respectively). This interval was not significantly different between the 2 groups of heifers.

The fall in progesterone concentration after the second $P G$ injection, and the timing of the occurrence and the duration of the LH peak were not significantly different between the groups.

The rate of post-ovulatory progesterone rise was determined by regression analysis of progesterone values obtained from the first detectable rise in progesterone values until slaughter. Analysis of variance showed that there was a significant increase in progesterone concentration with time, but there was no significant difference in the rate of rise of progesterone or in mean progesterone concentrations between cyclic and pregnant heifers.

The post-ovulatory progesterone rise of the pregnant subfertile cows $(N=11)$ in comparison with the pregnant heifer group $(\mathrm{N}=12$ ) (and the heifer group as a whole (pregnant and cyclic $(\mathrm{N}=25))$ is shown in Fig. 2. This progesterone rise was not detected in all animals since the time of the occurrence of the LH surge was so variable. Analysis of variance showed that the rate at which 


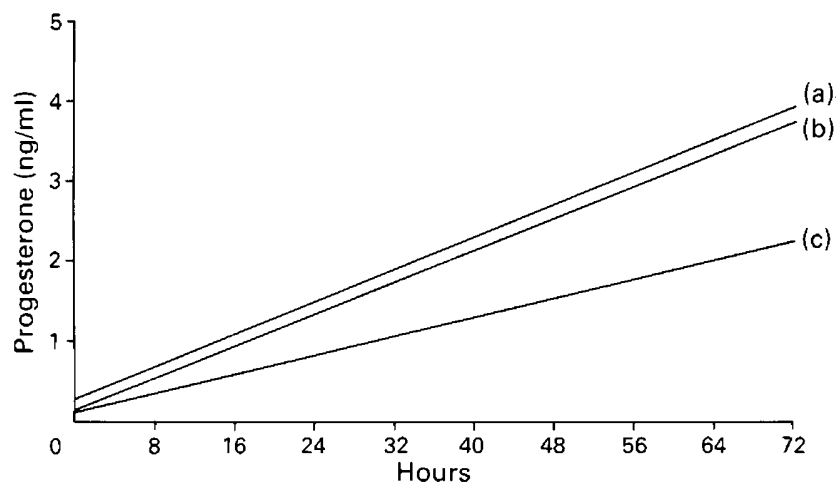

Fig. 2. The post-ovulatory rise in plasma progesterone in heifers and subfertile cows during the first 6 days of the oestrous cycle or pregnancy. The mean rate of rise of progesterone in the subfertile cows (c) $(\mathrm{N}=11)$ was significantly $(P<0.001)$ lower than in pregnant $(b)(\mathrm{N}=12)$ or pregnant and cyclic (a) $(\mathrm{N}=25)$ heifers.

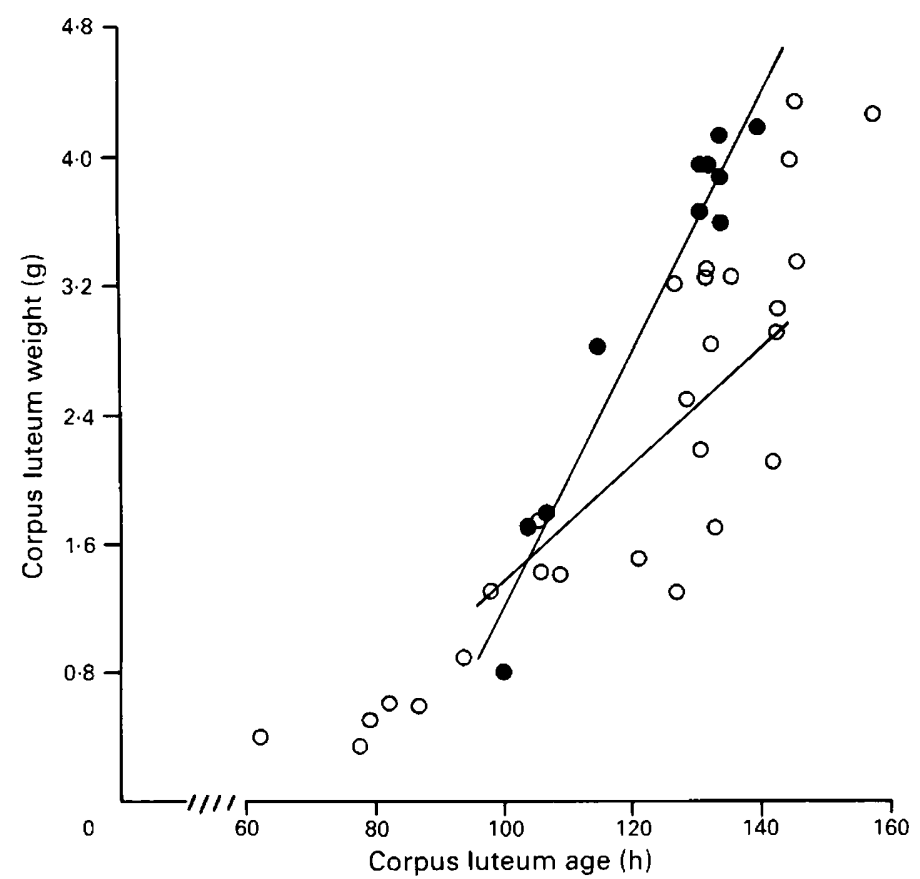

Fig. 3. Weights of corpora lutea recovered from pregnant and cyclic heifers $(O, N=27)$ and subfertile cows $(\Theta, N=11)$ during the early luteal phase. Linear regression lines were fitted on Day 5 and 6 for subfertile cows $(r=0.975, P<0.001)$ and heifers $(r=0.667, P<0.001)$. On Day $6(120-144 \mathrm{~h})$ cow corpora lutea were significantly $(P<0.001)$ heavier than those recovered from heifers.

the progesterone concentration rose in the blood was significantly $(P<0.001)$ lower in cows than in either group of heifers $(0.03$ vs $0.05 \mathrm{ng} / \mathrm{ml} / \mathrm{h}$ respectively).

The majority of the cattle were slaughtered on Day $6(120-144 \mathrm{~h})$ after the LH peak, as shown in Fig. 3. On this day, the corpora lutea of cows $(3.90 \pm 0.22 \mathrm{~g}(\mathrm{~N}=7))$ were significantly 


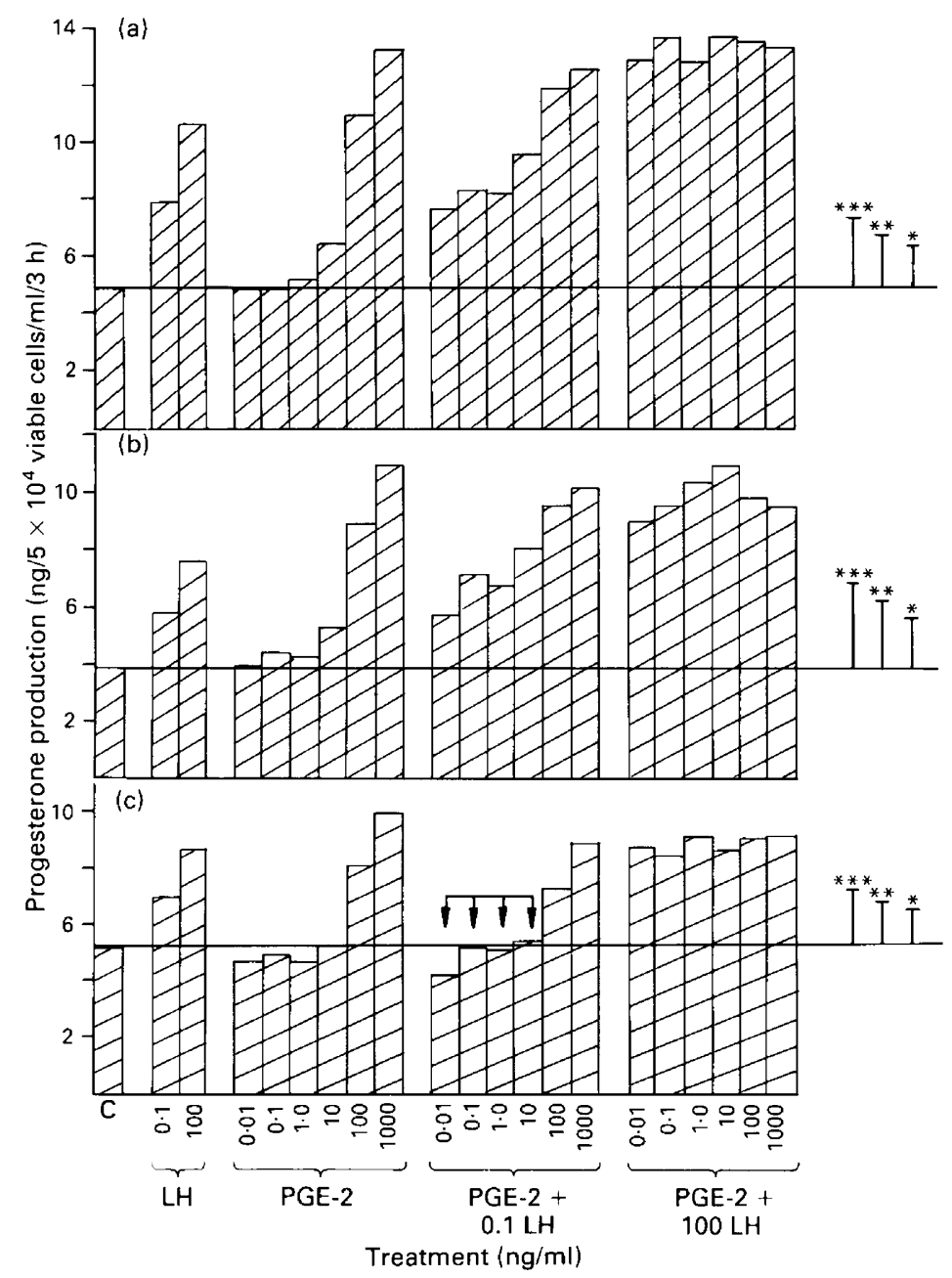

Fig. 4. Progesterone production by luteal cells dissociated from the corpora lutea of (a) cyclic heifers $(\mathrm{N}=10)$, (b) pregnant heifers $(\mathrm{N}=5)$ and (c) subfertile cows $(\mathrm{N}=11)$ on Day 6 of the oestrous cycle or pregnancy. Treatments were carried out in replicates of 5 , and thus each bar represents the mean of 50,25 and 55 observations in groups (a), (b) and (c) respectively. The s.e.d. used to make comparisons between the groups was $1.28 \mathrm{ng} / \mathrm{ml}$ and narrow bars show the significance level at which plasma progesterone production was different from the control. The arrows indicate significant inhibition of $\mathrm{LH}$-stimulated progesterone secretion, d.f. $=454 . \mathrm{C}=$ control. ${ }^{*} P<0.05 ;{ }^{* *} P<0.01 ;{ }^{* *} P<0.001$.

$(P<0.001)$ heavier than those of heifers $(2.54 \pm 0.72 \mathrm{~g}(\mathrm{~N}=13))$, but their age was not significantly different $(133.71 \pm 3.09$ and $132.92 \pm 6.64 \mathrm{~h}$ after $\mathrm{LH}$ peak).

\section{Luteal function in vitro}

As shown in Fig. 4, only animals from which corpora lutea were recovered on actual Day 6 (120-144 h after the LH surge) were included in the analysis. Analysis of variance showed that basal progesterone production was similar in all 3 groups (designated (a), (b) and (c) in Fig. 4). LH and PGE-2 had a significant effect $(P<0.001)$ on basal progesterone secretion and there was a 
significant $(P<0.001) \mathrm{LH} / \mathrm{PGE}-2$ interaction. The overall pattern of response to $\mathrm{LH}$ and PGE-2 was similar in the 2 groups of heifers; however, there was a significant $(P<0.001)$ difference in the pattern of response to the exogenous hormones in the cow group compared with the heifers. Comparison of the cow data with pooled data from the heifers showed that cow luteal cells were less sensitive to PGE-2 alone in that heifers cells showed a significant increase in progesterone production in response to $10 \mathrm{ng}$ PGE- $2 / \mathrm{ml}$, but the cow cells did not show a significant response unless PGE-2 was present at 100 or $1000 \mathrm{ng} / \mathrm{ml}$. In addition, although the effect of LH alone on cow luteal cells was not different from that of the heifers (both doses of LH caused a significant $(P<0.001)$ increase in progesterone production), stimulation of progesterone secretion by the low dose of LH was less in the presence of 0.01-10 ngPGE- $2 / \mathrm{ml}$ in luteal cells from subfertile cows. By contrast, the response of the heifer luteal cells to the low dose of $\mathrm{LH}$ under these conditions was not affected. The inhibitory effect of low doses of PGE-2 in the cow luteal cell incubations was overcome by high doses of PGE-2 and did not affect progesterone secretion stimulated by $100 \mathrm{ng} \mathrm{LH} / \mathrm{ml}$ in the presence of any dose of PGE-2 used.

\section{Discussion}

These results show that progesterone deficiency in the early luteal phase is related to age in the older cow and therefore may also be associated with embryo mortality in the older cow. The postovulatory rise in progesterone occurred later and concentrations of progesterone increased more slowly in the peripheral plasma of subfertile cows than in that of heifers. Also, the cow corpora lutea were larger than the heifer corpora lutea at a given chronological age. This suggests that, if their secretory activity was normal, progesterone should have been detected earlier and plasma concentrations would have increased more quickly than in heifers.

The in-vitro investigation demonstrated that this is unlikely to be due to an inability of the luteal cells of subfertile cows to synthesize progesterone from an endogenous substrate, since basal progesterone production by these cells was similar to that of cells from normal animals. However, there was a striking difference between the pattern of response of cow and heifer luteal cells to exogenous hormones, which indicated that the progesterone deficiency in the subfertile cows may have been caused by a diminished response to circulating luteotrophic hormones. In cow cells, low doses of PGE-2 inhibited the ability of a low dose of LH to stimulate progesterone synthesis. It is therefore possible that, in vivo, low concentrations of PGE-2 could exert a similar inhibition on the luteotrophic effects of systemic $\mathrm{LH}$ to reduce plasma progesterone concentrations in the subfertile cow. A similar antagonistic effect of PGE-2 on hCG stimulation of luteal cells from the rhesus monkey has been reported by Stouffer et al. (1979).

Since there was no evidence that the cow corpora lutea were morphologically abnormal (e.g. cystic), their larger size may imply that the cow corpora lutea were developmentally more advanced, possibly as ovulation could occur at an earlier point after the LH surge in the older cow. Alternatively, the cow corpora lutea may have actually developed at a faster rate. In addition, receptor numbers and affinity for the luteolysin PGF- $2 \alpha$ have been shown to increase with the development of the corpus luteum (Rao et al., 1979; Bartol et al., 1981). Therefore, if the corpora lutea were more mature, the presence of receptors for PGF- $2 \alpha$ could explain the decreased progesterone secretion.

The luteal deficiency observed in the early luteal phase of the subfertile cow has major implications in terms of embryo survival. The timing of changes in the uterine environment, upon which the normal embryonic development depends, is controlled by the time of the increase in progesterone concentration to levels typical of the luteal phase. It is possible to advance the timing of these uterine changes by administering progesterone in the early luteal phase of cattle (Woody et al., 1967; Woody \& Ginther, 1968; Ginther, 1970; Herring \& Lauderdale, 1980; Sreenan \& Diskin, 1983; Battista et al., 1984) and sheep (Miller \& Moore, 1976; Lawson \& Cahill, 1983). Hence, 
lowered progesterone concentrations and/or a change in ovarian steroid hormone ratios during this time could delay changes in the uterus, thereby resulting in asynchrony with the embryo. Indeed, embryo transfer experiments in cattle indicate that the uterine environment of repeat-breeders is suboptimal for the support of normal embryonic development (Almeida et al., 1984; Gustafsson \& Larsson, 1985). Further supportive evidence for this suggests that embryo survival is decreased in ewes with lower concentrations of progesterone immediately after oestrus (Ashworth et al., 1989; Wilmut et al., 1986), and passive immunization against progesterone leads to delayed embryo cleavage and embryo loss in mice (Feinstein et al., 1983; Heap et al., 1984). However, no difference in embryo cleavage between the older cows and younger heifers was noted in the present study.

The data obtained from the heifer study indicates that the embryo does not exert a measurable luteotrophic effect on the corpus luteum during the first 6 days of pregnancy, a result in line with our previous conclusions for milk progesterone data (Lamming et al., 1989). The use of frequent blood sampling in this study did not reveal differences between pregnant and cyclic heifers in plasma progesterone patterns during this period. The initial appearance of progesterone in the plasma of pregnant and cyclic heifers occurred at the same time, and the concentration and rate at which progesterone increased were also similar. Also, basal progesterone production and the pattern of response to $\mathrm{LH}$ and PGE-2 by dispersed luteal cells in vitro from pregnant and cyclic heifers were similar.

The importance of accurate detection of oestrus and ovulation in studies of this kind was emphasized when examining the data on the time of occurrence of the preovulatory LH peak after synchronization using cloprostenol. There was a variable response to synchronization, particularly in heifers, although ovulation occurred within the expected period for the type of synchronization programme used, i.e. 48-96 h after PG (Cooper \& Walpole, 1975). A few hours difference in the time of ovulation could mean relatively large differences in the progesterone concentration measured. In this study, by using the preovulatory LH peak as a reference point, an accurate comparison could be made.

The potential of PGE-2 in the regulation of the bovine corpus luteum has been demonstrated through its in-vitro effects. PGE-2 has a potent steroidogenic effect on dispersed luteal cells. However, it is also apparent that the action of PGE-2 is dependent on the dose used and on the physiological status of the target cells, since at low concentrations PGE-2 can inhibit LHstimulated progesterone synthesis. Subsequent work has failed to show a stimulatory effect on plasma progesterone in cyclic heifers infused by the intra-aortic route with graded doses of PGE-2, and administration of PGE-2 antiplasma to cyclic and pregnant sheep failed to affect either plasma progesterone concentrations or pregnancy rate (Parkinson, 1988; Parkinson et al., 1988).

In conclusion, this investigation has demonstrated that cows which are inherently subfertile have decreased progesterone secretion per unit weight of luteal tissue, reduced progesterone secretion in response to luteotrophic hormones and may also show an abnormal interaction between LH and PGE-2. It is suggested that these deficiencies may account for some of the early embryonic mortality in older cows.

We acknowledge financial support from the Milk Marketing Board of England and Wales, AFRC and MAFF.

\section{References}

Almeida, A.P., Ayalon, N., Faingold, D., Marcus, S. \& Lewis, I. (1984) The relationship between uterine environment and early embryonic mortality (EEM) in normal (NB) and repeat-breeder (RB) Friesian cows. Proc. I0th Int. Congr. Anim. Reprod. \& AI, Urbana 3, 438.
Ashworth, C.J., Sales, D.I. \& Wilmut, I. (1989) Evidence of an association between the survival of embryos and the preovulatory plasma progesterone concentration in the ewe. J. Reprod. Fert. 87, 23-32.

Ayalon, N. (1978) A review of embryonic mortality in cattle. J. Reprod. Fert. 54, 483-493.

Downloaded from Bioscientifica.com at $04 / 26 / 2023$ 02:12:26PM 
Ayalon, N. (1984) The repeat breeder problem. Proc. 10th Int. Congr. Anim. Reprod. and AI, Urbana 4, 111-141.

Ball, P.J.H. (1978) The relationship of age and stage of gestation to the incidence of embryo death in dairy cattle. Res. vet. Sci. 25, 120-122.

Bartol, F.F., Thatcher, W.W., Bazer, F.W., Kimball, F.A., Chenault, J.R., Wilcox, C.J. \& Roberts, R.M. (1981) Effects of estrous cycle and early pregnancy on bovine uterine, luteal and follicular responses. Biol. Reprod. 25, 759-776.

Battista, P.J., Rexroad, C.E., Jr \& Williams, W.F. (1984) Effects of the administration of progesterone and prostaglandin F-2 $\alpha$ prior to day 5 on luteal function in dairy heifers. Proc. 10th Int. Congr. Anim. Reprod. \& AI, Urbana 3, 502.

Boyd, H. \& Reed, H.C.B. (1961) Investigations into the incidence and causes of infertility in dairy cattleFertility variations. Br. vet. J. 117, 18-35.

Bulman, D.C. \& Lamming, G.E. (1978) Milk progesterone levels in relation to conception, repeat breeding and factors influencing acyclicity in dairy cows. $J$. Reprod. Fert. 54, 447-458.

Convey, E.M., Beal, W.E., Seguin, B.E., Tannen, K.J. \& Lin, Y.C. (1976) Gonadotrophin releasing hormone induced luteinizing hormone release after prostaglandin F-2 $\alpha$ in heifers. Proc. Soc. exp. Biol. Med. 151, 84-88.

Cooper, M.J. \& Walpole, A.L. (1975) Practical application of prostaglandins in animal husbandry. In Prostaglandins and Reproduction, pp. 309-328. Ed. S. M. M. Karim, MTP Press Ltd, Lancaster.

Erb, R.E., Garverick, H.A., Randel, R.D., Brown, B.L. \& Callahan, C.J. (1976) Profiles of reproductive hormones associated with fertile and non-fertile inseminations of dairy cows. Theriogenology 5, 227-242.

Feinstein, A., Heap, R.B., Rider, V., Wang, M.Y.\& Wright, L.J. (1983) Mechanisms by which anti-progesterone monoclonal antibody blocks pregnancy in mice. $J$. Physiol., Lond. 343, 125P, abstr.

Gayerie De Abreu, F., Lamming, G.E. \& Shaw, R.C. (1984) A cytogenetic investigation of early stage bovine embryos; relation with embryo mortality. Proc. 10th Int. Congr. Anim. Reprod. \& AI, Urbana. 2, 82.

Ginther, O.J. (1970) Effects of progesterone on length of estrous cycle in cattle. Am. J. vet. Res. 31, 493-496.

Gustafsson, H. \& Larsson, K. (1985) Embryonic mortality in heifers after artificial insemination and embryo transfer: differences between virgin and repeat breeder heifers. Res. vet. Sci. 39, 271-274.

Haresign, W., Foster, J.P., Haynes, N.B., Crighton, D.B. \& Lamming, G.E. (1975) Progesterone leveis following treatment of seasonally anoestrous ewes with synthetic LH-releasing hormone. J. Reprod. Fert. 43, 269-279.

Heap, R.B., Rider, V. \& Feinstein, A. (1984) Monoclonal progesterone antibodies and early embryo development. Proc. loth Int. Congr. Anim. Reprod. \& AI, Urbana 4, VIII-14.

Henderson, K.M. \& Moon, Y.S. (1979) Luteinization of bovine granulosa cells and corpus luteum formation associated with loss of androgen-aromatizing ability. J. Reprod. Fert. 56, 89-97.

Henricks, D.M., Dickey, J.F. \& Niswender, G.D. (1970) Serum luteinizing hormone and plasma progesterone levels during the estrous cycle and early pregnancy in cows. Biol. Reprod. 2, 346-351.

Henricks, D.M., Lamond, D.R., Hill, J.R. \& Dickey, J.F. (1971) Plasma progesterone concentrations before mating and in early pregnancy in the beef heifer. $J$. Anim. Sci. 33, $450-454$.

Herring, C. \& Lauderdale, J.W. (1980) Effect on the estrous cycle of progesterone and PGF- $2 \alpha$ administered during corpus luteum development. 72nd Ann. Meet. Am. Soc. Anim. Sci. 284 (abstr.).

Holness, D.H., Ellison, J.A. \& Wilkins, L.M. (1977) Conception of beef cows in relation to the concentration of progesterone in peripheral blood. Rhod. J. agric. Res. 15, 3-9.

Hunter, M.G., Southee,J.A., McLeod, B.J. \& Haresign, W. (1986) Progesterone pre-treatment has a direct effect on GnRH-induced preovulatory follicles to determine their ability to develop into normal corpora lutea in anoestrous ewes. J. Reprod. Fert. 76, 349-363.

Lamming, G.E., Darwash, A.O. \& Back, H.L. (1989) Corpus luteum function in dairy cows and embryo mortality. J. Reprod. Fert., Suppl 37, 245-252.

Lawson, R.A.S. \& Cahill, L.P. (1983) Modification of the embryo-maternal relationship in ewes by progesterone treatment early in the oestrous cycle. $J$. Reprod. Fert. 67, 473-475.

Lee, C.N., Critser, J.K. \& Ax, R.L. (1985) Changes of luteinizing hormone and progesterone for dairy cows after gonadotropin-releasing hormone at first post partum breeding. J. Dairy Sci. 68, 1463-1470.

Lukaszewska, J. \& Hansel, W. (1980) Corpus luteum maintenance during early pregnancy in the cow. $J$. Reprod. Fert. 59, 485-493.

Maurer, R.R. \& Chenault, J.R. (1983) Fertilization failure and embryonic mortality in parous and non-parous beef cattle. J. Anim. Sci. 56, 1186-1189.

Maurer, R.R. \& Echternkamp, S.E. (1982) Hormonal asynchrony and embryonic development. Theriogenology 17, 11-22.

Miller, B.G. \& Moore, N.W. (1976) Effects of progesterone and oestradiol on RNA and protein metabolism in the genital tract and on survival of embryos in the ovariectomised ewe. Aust. J. biol. Sci. 29, 565-573.

Parkinson, T.J.(1988) Endocrine studies of early pregnancy in the cow. Ph.D. thesis, University of Nottingham.

Parkinson, T.J., Kelly, R.W., Peters, A.R. \& Lamming, G.E.(1988) The effect of intra-aortic infusion of PGE-2 on luteal function of non-pregnant heifers. J. Reprod. Fert., Abstr. Ser. 1, Abstr. 105.

Randel, R.D., Garverick, H.A., Surve, A.H., Erb, R.E. \& Callahan, C.J. (1971) Reproductive steroid in the bovine $\mathrm{V}$ comparisons of fertile and non-fertile cows $0-42$ days after breeding. J. Anim. Sci. 33, $104-114$.

Rao, Ch.V., Estergreen, V.L., Carman, F.R. \& Moss, G.E. (1979) Receptors for gonadotrophin and prostaglandin F-2 $\alpha$ in bovine corpora lutea of early mid- and late luteal phase. Acta endocr., Copenh. 91, $529-537$.

Sreenan, J.M. \& Diskin, M.G. (1983) Early embryonic mortality in the cow: its relationship with progesterone concentration. Vet. Rec. 112, 517-521.

Sreenan, J.M. \& Diskin, M.G. (1986) The extent and timing of embryonic mortality in the cow. In Embryonic Mortality in Farm Animals, pp. 1-7. Eds J. M. 
Sreenan \& M. G. Diskin. Martinus Nijhoff Publishers, Dordrecht.

Stouffer, R.L., Nixon, W.E. \& Hodgen, G.D. (1979) Disparate effects of prostaglandins on basal and gonadotropin-stimulated progesterone production by luteal cells isolated from rhesus monkeys during the menstrual cycle and pregnancy. Biol. Reprod. 20, 897-903.

Tennant, J.R. (1964) Evaluation of the trypan blue technique for the determination of cell viability. Transplantation 2, 685-694.

Webb, R., Lamming, G.E., Haynes, N.B., Hafs, H.D. \& Manns, J.G. (1977) Response of the cyclic and postpartum suckled cows to injections of synthetic LHRH. J. Reprod. Fert. 50, 203-210.
Whittingham, D.G. (1971) Survival of mouse embryos after freezing and thawing. Nature, Lond. 233, $125-126$.

Wilmut, I., Ashworth, C.J. \& Sales, D.I. (1986) The influence of progesterone profile on embryo survival in ewes. In Embryonic Mortality in Farm Animals, pp. 135-141. Eds J. M. Sreenan \& M. G. Diskin. Martinus Nijhoff Publishers, Dordrecht.

Woody, C.O. \& Ginther, O.J. (1986) Effect of exogenous progesterone on corpora lutea in unilaterally hysterectomized heifers. J. Anim. Sci. 27, 1387-1390.

Woody, C.O., First, N.L. \& Pope, A.L. (1967) Effects of exogenous progesterone on oestrous cycle length. $J$. Anim. Sci. 26, 139-141.

Received 5 September 1989 